\title{
PERENCANAAN LOCAL AREA NETWORK
}

\section{(Local Area Network Planning)}

Susanto

Fakultas Teknologi Informasi dan Komunikasi Universitas Semarang

\begin{abstract}
Process planning of area local of network ( $L A N$ ) can be made one of consideration in making desain LAN network. Where good Process planning will get network matching with the one which we expect like clarifying requirement will be hardware, software, and network configuraton in context of problem, solution, and also business target.
\end{abstract}

Keywords: LAN, network.

\section{Pendahuluan}

Proses perencanaan jaringan komputer sekilas mungkin tampak menjemukan dan menghabiskan waktu, terutama apabila kita perlu mengimplementasi sistem baru secepat mungkin. Namun, perencanaan yang baik sangat penting bagi manfaat dan keandalan sistem kita, sama pentingnya dengan perangkat keras dan perangkat lunak yang hendak kita beli; jangan sampai diabaikan.

Melalui tulisan ini akan dibahas mengenai proses perencanaan jaringan komputer lokal atau local area network (LAN) yang bisa dijadikan salah satu pertimbangan dalam mendesain suatu jaringan.

Proses perencanaan untuk local area network (LAN) memiliki dua aspek yang perlu dicermati :

- Pertama, proses memberikan kepada Kita peluang untuk mengevaluasi ulang cara yang ditempuh oleh bisnis Kita selama ini dalam mengelola informasi. Kita juga dapat langsung menyesuaikan skema manajemen, dimana hal ini dapat menghemat atau menghasilkan uang dan dimana Kita dapat mengimplementasinya dengan atau tanpa bantuan komputer.

- Aspek kedua dari proses perencanaan adalah sesuai dengan yang kita harapkan: memperjelas kebutuhan Kita akan perangkat keras, perangkat lunak, dan konfigurasi jaringan dalam konteks masalah, solousi, dan sasaran bisnis.

Ketika proses berjalan kedua aspek ini sering dijalankan berulang kali: memilih jenis jaringan menyesuaikan kaidah bisnis dan mengubah proposal jaringan berdasarkan perubahan yang kita lakukan dalam bisinis kita.

Perancangan jaringan komputer dilaksanakan melalui sejumlah langkah. Beberapa langkah lebih penting dibandingkan langkah lainnya, tergantung dari jenis bisinisnya. Proses perencanaan delapan langkah untuk jaringan dalam bagian-bagian berikut adalah :

(1) Analisa kebutuhan ; (2) Analisa lokasi ; (3) Mencocokkan peralatan ; (4) Rencana konfigurasi ; (5) Struktur direktori server ; (6) Daftar konfigurasi ; (7) Jadwal konfigurasi (8) Catatan sistem (system log).

\section{ANALISA KEBUTUHAN}

Kita mungkin ingin memusatkan data agar ketepatanya meningkat, atau kita mungkin ingin berbagi periperal yang mahal harganya, atau mengoptimasi penjadwalan dan komunikasi kelompok kerja.

Langkah pertama dalam mengembangkan analisa kebutuhan adalah mengidentifikasi dan menulis permasalahan bisnis kita. Masalah bisnis adalah situasi yang 
akan merugikan kita apabila dibiarkan terus, atau sesuatu yang menghambat pemasukan tambahan yang kita rasa dapat diperoleh. Dengan perkataan lain, analisa kebutuhan yang efektif harus berpusat pada upaya menghemat atau menghasilkan uang. Ada banyak cara dimana jaringan (komputer standalone) dapat membantu kita menjalankan bisnis dengan lebih cepat atau lebih menguntungkan, tetapi perolehan tersebut belun tentu berarti uang dapat dihemat atau diperoleh. Tetapi sebaiknya kita perlu mencari situasi di mana tambahan teknologi dapat dikaitkan dengan keuntungan (bottom line).

Misalnya, komunikasi jaringan antar departemen pencatatan pemesanan dan departemen pengiriman dapat meningkatkan volume pengiriman. Selanjutnya kita dapat menetapkan insentif dalam proses pemesanan yang dapat mendorong peleanggan memesan barang dagangan dalam jumlah yang lebih banyak. meskipun hubungan antara jaringan dan meningkatnya pesanan mungkin tidak tidak terlalu jelas, tetapi hal itu benar-benar suatu kenyataan. Dalam proses perencaan berusahalah agar upaya memperkenalkan teknologi baru dilakukan bukan semata-mata demi kepentingan teknologi itu sendiri.

Berikut adalah beberapa contoh permasalahan bisnis umum lainnya yang mungkin dapat kita tangani dengan jaringan:

Kebutuhan akan Pemusatan Data : Apabila banyak pengguna menggunakan data yang sama, maka error dapat menjalar kecuali data disimpan di lokasi pusat yang diakses oleh semua pengguna. Hal ini tidak hanya berlaku untuk record bisnis seperti informasi pelanggan, pengiriman dan inventaris serta akuntansi; tetapi berlaku juga untuk informasi internal seperti bahasa boilerplate dan memo bisnis. Jenis informasi ini tidak begitu rentan terhadap error apabila disimpan, diakses dan diperbarui di satu lokasi. Sedikitnya error berarti berkurangnya waktu yang dihabiskan untuk memperbaikinya, membaiknya hubungan pelanggan dan karyawan, serta meningkatnya produktifitas.
Kebutuhan akan Otomatisasi : Kita dapat mengotomatisasi aliran kerja dengan mengirim file lewat jaringan. Dengan demikian aliran informasi lebih cepat dan kurang begitu rentan terhadap error. Seperti telah disebut di muka, berkurangnya error berarti menghemat uang. Kecepatan sangat penting, tetapi masih lebih penting ketepatan dan keandalan. Apabila aliran kerja yang lebih cepat berarti Kita dapat menangani lebih banyak informasi, dan peningkatan volome ini berarti semakin membesarnya laba, maka Kita dapat menggunakan alasan kecepatan bagi pengajuan usulan jaringan.

Kebutuhan akan Komunikasi : Kerap kali Kita dapat meningkatkan produktifitas dengan mempermudah komunikasi, baik di antara karyawan maupun antara karyawan dan pelanggan. Komunikasi, bila dipandang sebagai sarana untuk menghemat atau menghasilkan uang, adalah masalah persaingan. Misalnya : apabila Kita dapat melayani pelanggan lebih cepat dibandingkan yang lainnya, berarti Kita sudah memiliki keunggulan komunikatif.

Kebutuhan akan Keamanan : Asuransi sebesar apapun tidak mungkin dapat mengganti kerugian yang Kita derita dengan memadai akibat hilangnya data penting. Apabila bisinis Kita tidak dapat terhindar dari kehilangan data dalam sekala besar, Kita mungkin perlu menggunakan jaringan untuk mengotomatisasi prosedur backup : misalnya, rutin terotomatisasi dapat dijalankan setiap malam dan dapat menjamin bahwa record pada hari itu dari tidak penghapusan yangtidak disengaja.

Langkah selanjutnya dalam mengembangkan analisa kebutuhan adalah menerjemahkan permasalahan bisnis menjadi sasaran. Misalnya, apabila Kita tidak dapat menyediakan printer warna kecepatan-tinggi terpisah untuk setiap komputer stand-alone dalam bisnis Kita, maka sasaran Kita mejadi "implementasi sistem agar dapat berbagi printer warna kecepatan-tinggi tunggal". 
Menyatakan kembali permasalahan dalam bentuk sasaran memberikan kepada Kita peluang untuk mengukur hasil. Misalnya, kita dapat berkata "berbagai pen plotter-tunggal dapat menghemat ribuan dollar, dibandingkan biaya yang harus dikeluarkan untuk membeli beberapa peranti yang sama untuk masingmasing desktop"

Hal penting yang perlu diingat dalam kaintannya dengan langkah ini adalah upaya menuliskan apapaun yang dapat menghalangi bisnis kita dalam mencapai keuntungan, dan nyatakan kembali permasalahan tersebut dalam bentuk sasaran. Setelah itu, pertimbangka apakah jaringan komputer merupakan sarana yang tepat untuk mengimplementasi sasaran tersebut.

\section{ANALISA LOKASI}

Jaringan harus diinstal di lokasi yang sesuai. Cara terbaik dalam menentukan susuai tidaknya lokasi Kita bagi jaringan adalah dengan menggambar rencana lokasi (site plan). Untuk jaringan besar yang dapat mencangkup satu bangunan, atau antar bangunan, rencana lokasi kemungkinan cukup kompleks, bahkan termasuk dalam perencanaan arsitektur. Untuk jaringan lokasi kecil, rencana lokasi hanya berupa rencana lantai dasar.

Rencana lokasi yang baik berupa gambar yang mencangkup sejumlah informasi berikut:

- Dimensi ruang kerja untuk masing-masing karyawan pada jaringan yang diusulkan (penting dalam menentukan instalasi workstation dan server jaringan)

- Lokasi outlet listrik, termasuk piranti yang saat ini menggunakannya (penting dalam menentukan penyebaran beban listrik pada jaringan yang diusulkan)

- Lokasi seluruh obyek yang tidak dapat dipindah (misalnya:tiang penyangga, dinding penyekat atau lemari dalam dinding)

- Lokasi seluruh perabot yang ada saat ini (penting dalam menentukan layout jaringan keseluruhan, disamping lokasi untuk peranti yang digunakan bersama)

- Lokasi seluruh peralatan komputer yang ada saat ini (misalnya: PC desktop yang ada saat ini, disamping piranti periferal seperti printer)

- Lokasi pintu dan jendela (penting dalam memasang kabel)

- Lokasi seluruh ventilasi dan pengawatan listrik yang ada saat ini (penting dalam memasang sistem kabel untuk instalasi yang sangat besar)

\section{MENGINVENTARIS PERALATAN}

Saat menginventaris peralatan yang ada, kita harus membuat daftar ciri masingmasing item. Informasi ini sangat berharga dalam proses penetapan jaringan. Misalnya daftar ciri untuk komputer desktop stand-alone meliputi informasi seperti berikut :

Prosesor (misalnya,Intel P-III, 1000MHz)

Hard disk (misalnya, SeaGate $40 \mathrm{~GB}$ )

DVD-Combo (misalnya, Philips 52X)

Memori (SDRAM 512MB)

Monitor (misalnya, Samsung 15" SVGA)

Flopy Disk jika ada (misalnya, satu 3,5", 1.44MB)

\section{MENCOCOKKAN PERALATAN}

Apabila kita telah menyelesaikan analisa kebutuhan dan analisa lokasi, kita siap memulai proses pencocokkan jenis peralatan yang Kita perlukan dengan sasaran yang telah Kita identifikasi. Apabila Kita memiliki peralatan yang sudah ada sebelumnya yang hendak Kita sertakan dalam jaringan, maka pilihan kita mungkin sangat terbatas sehingga langkah ini praktis tidak berarti tidak banyak. sebaliknya, apabila Kita memulai dari awal, maka pekerjaan Kita cukup berat ; meskipun kita berkesempatan menghasilkan sistem yang sesuai dengan solusi yang di ajukan, namun kita juga harus memilih dari sekian banyak kemungkinan. Apabila kita masih ragu, konsultan yang berpengalaman dapat membantu kita memperjelas pilihan. 
Rekomendasikan dari pihak penjual harus spesifik dan menyebutkan merk dan versi perangkat keras serta perangkat lunak yang mereka usulkan, disamping harga termasuk instalasi dan layanan pemeliharaan yang diusulkan. Selain itu, pastikan bahwa penjual juga memperhitungkan masalah kompatibilitas berkenaan dengan peralatan Kita yang ada saat ini. Jangan lupa mendapatkan garansi dari penjual bahwa semua perangakat keras baru dan yang sudah ada yang hendak Kita gunakan terutama NIC kompatibel dengan versi sistem operasi jaringan yang diusulkan.

Sediakan waktu untuk memperhitungkan besar beban listrik yang disyaratkan oleh sistem yang diajukan. Masalah ini bisa menjadi sesuatu yang sifatnya mendesak terutama apabila kita menginstal jaringan di dalam bangunan kuno. Mintalah informasi tentang spesifikasi listrik dari pemilik atau pihak pembangunan gedung.

Disamping itu jangan lupa biarkan dengan penjual Kita tentang masalah kabel. Dengan menggunakan rencana lokasi kita, kita harus mengestimasi dengan baik pemasangan kabel yang kita kehendaki di lokasi dan seberapa panjang segment kabel tersebut. Penjual yang baik harus dapat menujukkan apakah pilihan kita dibatasi oleh persyaratan kabel.

\section{Rencana Konfigurasi}

Rencana konfigurasi jaringan Kita didasarkan atas rencana lokasi dan mencakup peralatan yang baru ditambahkan dan direlokasi. Yang terpenting, kita dapat menggunakan rencana lokasi untuk menggambar alur kabel dan menentukan panjang kabel yang dibutuhkan untuk menghubungkan jaringan.

Keamanan kabel sangat penting. Sewaktu kita menggambar rencana konfigurasi, catat tempat-tempat dimana kabel akan terlihat. Berbuatlah sebisa mungkin untuk menyembunyikan kabel dari pandangan mata (karena kabel yang menggantung memang tidak sedap dipandang) tetapi terutama agar tidak terinjak kaki. Tersandung kabel dapat dapat mengabatkan hilangnya produktivitas akibat cedera adapter cardter lepas, dan workstation terjatuh dari meja. Apabila kabel harus melewati daerah yang sering di injak pasang penutup kabel. Penutup kabel adalah jenis karet keras yang terlihat seperti speed bump. Kemungkinan tersangdung kecil sekali, hampir tidak kelihatan dan dapat menjamin keamanan kita sehingga kita tidak perlu memikirkannya.

\section{Struktur Direktori Server}

Struktur direktori server adalah himpunan alamat logika yang diberi nama pada hardisk server yang mengorganisasi file disk terkait ke dalam kelompok logika dan memudahkan pencariannya. Struktur direktori dimulai dengan direktori akar yang biasanya menampung direktori lai, yang pada gilirannya dapat menampung file disk atau direktori lagi.

Terdapat jenis file tertentu yang dapat dujumpai pada bagian server. Jenis ini meliputi:

- File sistem operasi jaringan.

- File sistem client.

- File aplikasi.

- File data pengguna.

- File data yang dugunakan bersama

- File e-mail

Berikut adalah beberapa contoh nama direktori yang sifatnya umum :

APPS : Ini adalah nama direktori yang agak standar sifatnya untuk aplikasi perangkat lunak yang harus dijalankan pada jaringan, atau diakses dari jarak jauh dan di jalankan secara lokal. Biasanya direktori APPS tidak berisi file, melainkan berisi direktori lagi, di mana masing-masing direktori menampung aplikasi terbisah serta filefile sistem terkaitnya. Aplikasi ini sering kali di instal dengan menggunakan perangkat lunak instalasi otomatis, yang akan membuat direktori tambahan di bawah direktori nama 
aplikasi indifidu. Biarkan sruktur dalam kondisi seperti itu, kecuali Kita terpaksa harus memindahkan file sistem aplikasi dan mengubah struktur direktori aplikasi.

DATA : Direktori ini biasanya menampung direktori lain, yang berisi file data yang sifatnya unik bagi aplikasi tertentu. Misalnya, bisa saja ada sub direktori bernama WP di dalam direktori DATA, yang menampung file dokumen untuk program pengolah kata tertentu.

LOGIN : Direktori ini yang tampak dalam NetWare (diantara sistem operasi lainnya), adalah direktori yang di log pertama kali oleh client sewaktu mengakses sistem jaringan. Apabila pengguna telah mengadakan hubungan awal, ia dapat menjelajahi struktur direktori sesuka hatinyaasalkan ia memiliki hak akses yang memadai.

MAIL : Direktori ini menampung database pesan yang dikirim dan diterima pada sistem komunikasi e-mail jaringan.

PUBLIC : Terlihat dari nama, direktori ini menampung file dan direktori lain yang dapat diakses dari hampir sembarang tempat pada jaringan. Meskipun direktori ini kerap diberi batasan baca saja, namun direktori ini bukanlah tempat untuk menyimpan data yang terjamin keamanannya. Misalnya, di bawah PUBLIC. Kita mungkin perlu membuat sub direktori yang menampung utility untuk sistem oprasi tertentu yang di gunakan pada berbagai workstation client. Dengan menyimpan utility di lokasi ini, maka utility tersebut dapat di akses oleh siapapun pada jaringan yang membutuhkannya.

USERS : Ini adalah nama direktori umum untuk file data yang menjadi milik pengguna individu pada jaringan. Direktori USER seringkali tidak berisi file, melainkan berisi direktori privat bagi pengguna sistem.

Struktur direktori yang buruk bisa saja tercipta. Berikut adalah beberapa prinsip umum berkenaan dengan apa saja yang perlu dihindari:

Direktori yang perlu dangkal : Kita dapat membuat seluruh direktori file satu tingkat di bawah direktori akar. Sementara set-upnya mudah dilakukan, struktur ini sangat tidak efisien karena jaringan dan pengguna harus menelusuri daftar panjang direktori yang tidak ada hubunggannya dalam upaya mencari sesuatu.

Direktori yang terlalu dalam : Tidak terlalu baik jika subdirektori disarankan berlebihan satu di bawah lainnya. Yak seorangpun ingin log ke deretan panjang direktori seperti IUSERIELAINEIWPIMEMOSIINTEROFF untuk mencari memo antar kantor Elaine. Usahakan agar subdirektori Kita bersarang tidak lebih dalam dari tiga atau empat tingkat, kecuali struktur direktori yang dihasilkan oleh rutin instalasi perangkat lunak otomatis.

Nama pengguna kembar : Meskipun direktori pengguna bisa saja diberi nama USERIKIKY sedang direktori lain di beri nama APPSIWORDIKIKY, namun jenis rancangan seperti ini biasanya termasuk dalam kategori organisasi yang tidak begitu baik. Apabila dua direktori atau lebih mengacu ke pengguna yang sama, coba rancang ulang struktur agar seluruh file data pengguna tersusun di bawah satu direktori pengguna.

\section{DAFTAR KONFIGURASI}

Setelah menggambar rencana konfigurasi, Kita harus membuat beberapa daftar penting. Kita harus membuatnya secara hati-hati, karena informasi akan masuk ke dalam system log jaringan :

Daftar Nama Mesin : Kita harus memberi nama yang unik untuk tiap workstation dan server pada jaringan. Memilih nama ini biasanya dengan mudah dapat dilakukan. Biasanya mesin diberi nama untuk pengguna 
atau fungsinya dalam jaringan. Perlu diingat bahwa nama mesin bukanlah password, dan umumnya bukan bagian dari sistem keamanan.

Daftar Direktori Server : Daftar ini memuat struktur direktori untuk tiap server pada jaringan. Dalam bentuknya yang paling sederhana, dapat berupa hasil cetak sederhana dari pohon direktori. Banyak sistem operasi jaringan memiliki utility untuk menghasillkan hasil cetak ini. Hasil cetak (hard copy) struktur direktori dapat membantu, misalnya apabila terjadi kegagalan pada server. Hasil cetak set-up sistem dapat mempercepat proses pembangunan kembali (rebuilding).

Daftar Pengguna Server : Dapat membantu dalam membuat daftar nama mesin, untuk tiap server, dengan akses je server tersebut. Disamping nama mesin, daftar harus menyertakan informasi seperti jadwal login (hari dan waktu pada saat akses diijinkan), hak akses, batas tanggal login (jika ada), dan jadwal pembaruan password.

Daftar Printer : Daftar ini harus mencangkup informasi konfigurasi untuk tiap printer pada jaringan. Sertakan nama printer port komunikasinya pada print server (misalnya, LPT1 atau COM1) baud rate (jika dapat digunakan) serta konfigurasi defaultnya. Daftar ini dapat menghemat waktu dan membuat Kita tidak perlu menebak-nebak apabila kita perlu mengganti printer karena alasan tertentu.

\section{JADWAL KONFIGURASI}

Jadwal instalasi perlu di buat karena dengan demikian kita berkesempatan membuat mengetahui secara menyeluruh proses instalasi jaringan dalam bisnis kita secara fisik. Bila memungkinkan, mintalah nasehat dari seseorang yang telah menginstal sistem seperti milik kita. kita harus menyediakan waktu untuk langkah-langkah instalasi berikut :

Langkah 1 - Pembelian Peralatan : Bersiapsiaplah jika terjadi kelambatan pengiriman. Apabila seluruh peralatan tidak tiba sesuai jadwal, mungkin lebih baik memundurkan jadwal instalasi secara keseluruhan hingga seluruh peralatan yang di perlukan tiba. Kita harus menghindari terjadinya downtime (terhentinya kegiatan karena suatu hal yang tidak terduga) berkepanjangan sewaktu jaringan telah diinstal sebagian dan Kita harus menunggu tibanya part (bagian) penting (misalnya : printer atau segmen kabel).

Langkah 2 - Baca Manual : Paling tidak bacalah bagian manual yang berhubungan dengan pilihan instalasi dan konfigurasi. Peralatan komputer berubah dengan cepat dan bisa saja konfigurasi yang telah kita antisipasi mengalami pembaruan.

Langkah 3 - Persiapan Lokasi : Berarti memindahkan perabot, menyingkirkan peralatan yang sudah usang, menginstal outlet listrik yang baru dan sejenisnya. (mungkin ini ada mitra kerja yang dapat membantu kita dalam hal ini sementara Kita membaca semua manual tersebut).

Langkah 4 - Backup Data Kita : Langkah yang tampaknya kurang begitu penting, tetapi sebenarnya sangat penting. Bila saja file kita rusak, dan kita tidak memiliki backupnya. Pandang langkah ini sebagai asuransi instalasi. Tak seorangpun bisa mersa dirugikan apabila backup tidak digunakan.

Langkah 5 - Set Up Perangkat Keras : Sekarang paling tidak kita mulai bekerja dengan semua peralatan baru tersebut. Hal paling penting untuk diingat terkait dengan tahap ini adalah agar Kita menyediakan waktu. Tindakan yang tidak cermat pada tahap ini dapat menghancurkan jaringan. Periksa ulang semua setting saklar (switch) serta setting jumper pin (jika ada), sekalipun Kita menggukan setting default -nya yang katanya sudah ditetapkan pada waktu produk tiba di tempat.

Langkah 6 - Instal Perangkat Lunak : Mungkin tahap ini adalah tahap paling menghabiskan waktu. Sekali lagi, sediakan waktu dan periksa ulang seluruh stting konfigurasi. Pada tahap ini kesalahan adalah sesuatu yang lazim terjadi; terima saja apapun yang terjadi dan adakan perbaikan yang diperlukan. Jangan biarkan perhatian Kita 
dirusak oleh tekanan yang ada dalam upaya merampungkan proyek. Hadapai para penonton dan mereka yang suka ikut campur urusan orang lain dengan senyum penuh percaya diri namun tersirat kesan yang mengingatkan mereka bahwa mereka pun harus merampungkan pekerjaan mereka sendiri.

Langkah 7 - Uji, Uji, Uji, : Kita mungkin tidak bisa melakukan banyak pengujian. Yang terutama adalah Kita harus menguji layanan printer. Masalah serta kelambatan pada jaringan sering kali terkait dengan pencetakan. Sasarannya adalah mencari dan meniadakan bug sistem sebelum pengguna log. Dalam prakteknya, hal ini hampir tidak dapat dilakukan karena pengguna memiliki kebiasaan kerja dan kekhasan yang dapat menimbulkan masalah yang tidak pernah kita antisipasi. Namun langkah berikut dapat membantu.

Langkah 8 - Pelatihan : Pelatihan terdiri dari dua tingkat. Pada tingkat pertama, Kita harus membiasakan pengguna dengan fasilitas jaringan dan mengawasi tindakan awal mereka hingga mereka terbiasa dan merasa senang dengan apa yang di harapkan dari mereka. Pada tingkat kedua, Kita harus melatih mereka mengikuti prosedur tertentu apabila terjadi masalah. Seperti halnya dengan tahapan lain, Kita harus menyediakan banyak waktu, disamping waktu tambahan terjadwal apabila pengguna memintanya.

\section{CATATAN SISTEM}

Sistem log sebenarnya adalah dokumentasi jaringan. Tujuan dari sistem log ini adalah menyediakan riwayat rinci tentang seluruh perangkat keras, perangkat lunak dan konfigurasi jaringan. Sumbar daya yang sangat berharga sewaktu hendak memecahkan suatu permasalahan.

Satu-satunya cara untuk menyimpan sistem log yang akurat adalah dengan memulainya sedini mungkin menulis seluruh informasi sistem sebagai rancangan Kita dan menginstal sistem. Bila Kita manager sistem untuk jaringan Kita, jangan abaikan pekerjaan penting ini. Berikut adalah beberapa item yang mungkin perlu Kita sertakan dalam sistem log Kita :

Garansi Perangkat Keras : Sediakan terpisah untuk perjanjian garansi perangkat keras Kita. Golongkan berdasarkan jenisnya: monitor, network interface card, hard disk. Apabila peralatan merupakan bagian dari workstation atau server, tambahkan nama mesin pada garansi dan arsipkan berdasarkan nama mesin.

Informasi Peralatan : Untuk tiap perangkat keras yang terpasang pada masingmasing mesin, simpan dan catat nomor serial, buatan, setting konfigurasi, nama dan nomor telepon penjual.

Buku Harian Setup Sekarang : Simpan rincian struktur direktori dan konfigurasi sistem operasi sekarang dalam bagian terpisah. Jangan lupa menyertakan tanggal instalasi konfigurasi. Tambahkan informasi konfigurasi yang baru dan sudah diperbaruhi di muka informasi yang lama - tetap simpan konfigurasi lama.

Rencana Backup : Manajemen jaringan yang baik mencakup rencana backup rinci. Rencana backup ini harus dicacat tinggalnya, dituli dan disimpan dalam system log. Tambahkan update (pembaruan) yang baru tercatat atas rencana backup ssesuai yang diperlukan, tetapi rencana lama perlu disimpan untuk referensi.

Backup Log (Catatan Backup) : Kita harus menyimpan catatan bilamana backup dilakukan dan siapa yang bertanggung jawab. Apabila prosedur backup terotonatisasi, maka server yang bertanggung jawab atas backup dapat mencetak laporan, yang dapat Kita arsipkan di sini.

\section{KESIMPULAN}

Dari pembahasan diatas dapat ditarik kesimpulan bahwa keberhasilan suatu jaringan komputer tidak dapat dilepaskan dari proses perencanaan pembuatan jaringan yang baik sehingga sangat bermanfaat dan menjadikan sistem kita handal. Selain itu perencanaan 
dengan menganalisa kebutuhan yang efektif, dilakukan dalam upaya menghemat atau menghasilkan uang.

Proses perencanaan pembuatan jaringan komputer yang baik akan menghasilkan sistem jaringan sesuai dengan yang kita harapkan seperti memperjelas kebutuhan akan perangkat keras, perangkat lunak, dan konfigurasi jaringan dalam konteks masalah, solusi, serta sasaran bisnis.

\section{DAFTAR PUSTAKA}

1. Arifin, Zaenal, Langkah Mudah Membangun Jaringan Komputer, Andi, 2005

2. Currid, Cherryl C. \& Gillet, Craig A., Menguasai Novell Netware, Elex Media Komputindo, 1993

3. Lukas Tanutama dan Hosea Tanutama, Mengenal Local Area Network (LAN), Elex Media Komputindo, 1991

4. Robert M. Thomas, Pengantar Local Area Network (LAN), Elex Media Komputindo, 1996

5. Sudantha Wirija, Ir., Singkat Tepat Jelas Windows NT 4.0, Elex Media Komputindo, 1998

6. Stallings, W. Local Network, Macmillan Publishing Company, 1985.

7. Tanenbaum, AS, Computer Networks, Prentise Hall, 1996 